\title{
Struktuur en boodskap(pe) in die boek Daniël
}

\author{
H J M van Deventer \\ Potchefstroomse Universiteit vir Christelike Hoër Onderwys \\ Vaaldriehoekkampus, Vanderbijlpark
}

\begin{abstract}
Structure and message(s) in the book of Daniel

The book of Daniel presents a number of challenges that scholars have not yet been able to solve. This article focuses on the problem related to the bilingual character of the book of Daniel (Hebrew and Aramaic) and the fact that the two languages do not correspond with the two literary types found in the book (court tales and visions). From a structural perspective this phenomenon is utilised to indicate specific accentuated sections in the book of Daniel. On the basis of these findings, suggestions are made regarding messages in the book. These suggestions combine historical and literary approaches to the text.
\end{abstract}

How the text speaks and what it says belong together in the discovery of what it is

Phyllis Trible

... sacred texts contain a religious message which is other than that which can be immediately inferred from the manifest sense of the narrative

Edmund Leach

\section{INLEIDING}

Die boek Daniël bied 'n hele paar uitdagings waarop navorsers tot op hede nog nie ten volle bevredigende oplossings kon bied nie. Hierdie probleme sluit onder andere die volgende in: (1) die sosio-historiese agtergrond waarteen die boek verstaan moet word; (2) die tweetalige aard van die boek waarvolgens Daniël 1:1-2:4a in Hebreeus, Daniël 2:4b-7:28 in Aramees en Daniël 8:1-12:13 weer in 
Hebreeus geskryf is; en (3) die twee duidelik onderskeibare literatuursoorte wat aangetref word, naamlik hofvertellinge in Daniël 1 - 6 en visioene in Daniël 7-12. Die probleem waarop hierdie artikel fokus sluit aan by die tweetaligheid van die boek en juis die feit dat die twee tale wat voorkom nie oorvleuel met die twee literatuursoorte nie.

Hierdie artikel wil nagaan tot watter mate die strukturering van die materiaal in die boek, onder andere in twee tale, as 'n sleutel kan dien vir 'n boodskap of boodskappe wat die boek wil kommunikeer. Dit het nie ten doel om die studieresultate volledig toe te pas op die interpretasie van die boek nie. In hierdie verband word slegs 'n aantal voorstelle aan die einde van die artikel gemaak.

Eerstens word die probleem rondom die tweetaligheid van die boek kortliks belig. Daarna word op 'n bepaalde benadering tot die teks gefokus asook die moontlikhede wat dit vir Bybelverklaring inhou. Hierdie benadering plaas die klem op die struktuur waarin die boek gegiet is. Daar word uitgegaan van die literêr-kritiese standpunt dat die wisselwerking tussen die vorm (in hierdie geval struktuur) en inhoud van 'n teks, bydrae tot betekenis (dit is natuurlik slegs een van vele standpunte binne die literêr-kritiese benadering tot 'n teks). Daar moet toegegee word dat hierdie standpunt 'n getemperde siening van strukturalisme is. Eagleton (1983:95) meen dat 'n volbloed ("card carrying") strukturalis nie sou belangstel in die wisselwerking tussen vorm en inhoud nie, maar bloot op die vorm (struktuur) sou konsentreer. Barton (1996:122-123) wys egter daarop dat 'n meer getemperde siening aangaande strukturalisme binne die Bybelwetenskappe bestaan.

\section{TWEE TALE IN EEN BOEK}

Die probleem met betrekking tot die tweetaligheid van die boek Daniël en veral dat die gebruik van die twee tale nie ooreenstem met die twee literatuurtipes in die boek nie, is al deur Davies $(1985: 15,35)$ beskryf as "perhaps the most perplexing of all the peculiarities of the book" wat uiteindelik "inexplicable" mag wees. Dit mag egter wees dat hierdie "probleem" in die finale teks moontlikhede inhou vir die bestudering van struktuur in die boek Daniël. Hierdie twee tale 
verteenwoordig reeds ' $n$ basiese struktuur waarvolgens die boek in drie dele ingedeel kan word: 'n inleidende gedeelte in Hebreeus (1:1-2:4a), 'n Aramese gedeelte (2:4b-7:28) en 'n Hebreeuse gedeelte (8:1-12:13). Hieronder sal hierdie drie dele in diepte ontleed word met die oog op die identifisering van verdere strukturele patrone.

Baldwin (1978:59) het probeer om wel die taalaspek in aanmerking te neem in haar onderskeiding van "an A-B-A pattern in the over-all structure". Hierdie patroon word saamgestel uit die Hebreeuse eerste deel $(A)$, die Aramese tweede deel (B) en die Hebreeuse derde deel (A). Hierdie onderskeid word gemaak met 'n beroep op 'n soortgelyke literêre tegniek in "other books (sic!) from the Ancient Near East". Die "ander boeke" wat in hierdie verband geïdentifiseer word, is die wettekodeks van Hammurabi en die boek Job (vgl. Baldwin, 1978:39). Hammurabi word betrek op grond van die feit dat die proloog en epiloog by die wette in "semi-poëtiese" Akkadies geskryf is, terwyl die wette self in prosavorm is, en Job vanweë die prosaïese inleiding en slot, met die res van die boek in poëtiese vorm. Wat Baldwin egter nie met hierdie onderskeid verdiskonteer nie, is dat in hierdie tekste waarop sy haar beroep, die A-B-Apatroon nie op grond van verskillende tale nie, maar op grond van verskillende literatuursoorte geïdentifiseer word. Indien dieselfde kriterium op die boek Daniël van toepassing gemaak word, sou die algemeen aanvaarde tweedeling van die boek in vertellinge (Daniël 1-6) en visioene (Daniël 7-12) gehandhaaf moes word. In hierdie opsig geld Bar-Efrat (1980:172) se waarskuwing dat struktuurpatrone nie op grond van verskillende kriteria geïdentifiseer kan word nie.

'n Struktuurpatroon wat vir die boek Daniël geïdentifiseer word, sal moet erns maak met beide die onderskeid in taal en literatuursoort wat in die boek aangetref word. 'n Resente poging in hierdie verband is dié van Wesselius (2001:293-310). Wesselius (2001:294) neem as vertrekpunt die finale vorm van die boek om aan te toon dat die probleem rondom taal en literatuursoort in die boek nie verband hou met historiese (redaksionele) faktore nie, maar eerder met 'n bepaalde literêre strategie wat die tweede-eeuse outeur van die boek gebruik het. Hierdie strategie behels dat die outeur van die Daniël-"dossier" die teks geproduseer en daarna gerangskik het in 'n bepaalde vorm. Hierdie vorm is 
volgens Wesselius (2001:299 ev) afgelei uit die boek Esra wat as model gedien het vir die strukturering van die materiaal. Ten spyte van Wesselius (2001:305) se poging om met sy verduideliking van Daniël se "strukturele afhanklikheid" van Esra nie in te veel "tegniese detail" te verval nie, is sy voorstel redelik tegnies. Wesselius bied 'n vars antwoord op 'n ou probleem', maar kritiek daarop sou wees dat dit baie tegnies is en historiese probleme, soos die volgorde waarin Esra en Nehemia opgetree het, nie verdiskonteer nie. Die voorstel wat hieronder vir dieselfde probleem aangebied word, poog om minder tegnies te wees, terwyl dit ook historiese faktore binne die tweede-eeuse milieu in ag sal neem.

\section{STRUKTUUR AS SLEUTEL TOT 'N BETEKENIS? ${ }^{2}$}

\section{1 'n Kort oorsig oor strukturalisme}

lemand het lank terug opgemerk dat dit lyk asof daar geen einde aan die skryf van boeke is nie (vgl. Prediker 12:12). In dieselfde trant kan opgemerk word dat dit lyk asof daar geen einde aan die interpretasie van boeke is nie. Die groot ontwikkeling in die literatuurteorieë gedurende die twintigste eeu het daartoe gelei dat literêre werke gelees en herlees is vanuit verskillende gesigspunte. Hierdie "nuwe gesigspunte" waaruit daar na literatuur gekyk is, het nie tot "algemene" literatuur ${ }^{3}$ beperk gebly nie. Die insigte wat moderne literatuurteorieë gebied het, is ook op die Bybel van toepassing gemaak. Een van hierdie "nuwe" insigte met betrekking tot die lees en verklaring van 'n teks staan bekend as strukturalistiese studies. Strukturalisme word huidig nie meer onder die noemer

1 Die probleem met "vars" antwoorde is dat dit dikwels bestaande konsensus oor sommige sake ook negeer (vgl. in hierdie verband Aaron [2001:308-309] se opmerkings aangaande Buchanan [1999] se kommentaar op die boek Daniël waarin die boek gesien word as 'n oorwinningsgeskrif ná die Makkabeër-opstand).

2 Vir enkele opmerkings aangaande die gebruik van die verskeidenheid "nuwe" insigte uit die literatuurwetenskap in die interpretasie van die Bybel word verwys na Clines en Exum (eds) (1993) en uit eie bodem na Schultze (1988:141, 150-151) en Combrink (1988:129).

${ }^{3}$ In hierdie studie word 'n onderskeid getref tussen algemene ("sekulêre") literatuur en die Bybel. Hierdie onderskeid word egter nie deur alle navorsers gehandhaaf nie. Alter (1981:12-13) benader byvoorbeeld die Bybel op dieselfde wyse as wat hy die klassieke werke van Dante, Shakespeare en Tolstoy sal benader, alhoewel die religieuse karakter van die Bybel nie ontken word nie. 
van "nuwe" insigte tot die lees van 'n teks tuisgebring nie. Clines en Exum (1993:16) meen die benadering is nie meer "nuut" nie, alhoewel dit nie beteken dat hierdie benadering geen nut meer het in die interpretasie van tekste, of dat die resultate van hierdie benadering in die lig van die nuutste ontwikkelinge in die literêre kritiek ongeldig is nie.

Die verhaal van strukturalisme begin tot ' $n$ groot mate by die werk van die Sweedse linguis Ferdinand de Saussure (1857-1913). Hierdie verhaal is in verskillende variasies reeds vertel (vgl onder meer Stevens \& Stewart [1987:3342] vir 'n korter en Eagleton [1983:91-126] vir 'n langer variasie). Ek gee hier bloot 'n oorsig van die belangrikste momente in hierdie verhaal. Saussure se werk is eers na sy dood deur van sy kollegas en studente gepubliseer. Twee van Saussure se insigte is van belang. Eerstens onderskei Saussure tussen langue (onderliggende reëls aangaande onder meer woordorde, grammatika, tyds- en ander sintaksiese elemente) waardeur 'n persoon in staat gestel word om nuwe taaluitinge (parole) te maak. Dit is die taak van die strukturalis om die beginsels (langue) onderliggend aan individuele stellings (in die teks) (parole) te ontleed (vgl Saussure 1988a:7-8). Tweedens onderskei Saussure tussen taal en dit waarna taal heenwys. Daar bestaan naamlik 'n aanduier (die klankbeeld), 'n aangeduide (die konsep) en 'n teken (die [kultureel-bepaalde en daarom arbritrêre] kombinasie van die twee) (vgl Saussure 1988b:10-11). Om te bepaal watter wette die strukturele relasies van tekens beheers, is die wetenskap van semiotiek deur Saussure (1988a:8-9) voorgestel.

Hierdie insigte sou deur die Russiese formalis Vladimir Propp gekonkretiseer word in sy analise van Russiese volksverhale ${ }^{4}$. Propp het ontdek dat elke volksverhaal (parole) gebou is op 'n bepaalde stel konvensies (langue) wat dit met ander volksverhale deel (vgl Stevens \& Stewart 1987:34-36). In wese sou strukturalistiese studies nie in die eerste plek poog om 'n teks te interpreteer nie, maar om die ("dieper") strukture onderliggend aan die teks bloot te lê. Die blootlê van hierdie onderliggende strukture sou egter, teoreties beskou, nie so 'n eenvoudige aangeleentheid wees nie. Die onderskeiding van bepaalde strukture in 'n teks veronderstel ' $n$ volgende stel strukture op grond waarvan die eerste

${ }^{4}$ Vgl Milne (1988:23-26) vir die verband tussen Saussure en Propp. 
onderskeiding gemaak is. Hierdie studie gaan nie dieper in op die teoretiese begronding nie, maar daar kan verwys word na Ray (1984:110-140) wat 'n kritiese oorsig gee van twee literêre teoretici, Jonathan Culler en Umberto Eco, wat hierdie teoretiese begronding verder uitgewerk het.

Gérard Genette (1988:66) het strukturalisme beskryf as 'n benadering wat "vir 'n tyd lank" in die ontleding van literêre werke gebruik sou kon word. Hy het moontlik reeds die teoretiese probleme waarna verwys is, aangevoel ( $\mathrm{vgl}$ Genette, 1988:68). Hierdie probleme in die teorie van strukturalistiese kritiek sou, nadat dit op die spits gedryf is, lei tot die geboorte van dekonstruksie as vorm van literêre kritiek. Genette (1988:66) gee die volgende definisie van strukturalistiese kritiek: "Structuralist method as such is constituted at the very moment when one recovers the message in the code, uncovered by an analysis of the immanent structures and not imposed from the outside by ideological prejudices" (my kursivering).

Die strukturaliste se siening aangaande die "dieper" strukture in 'n teks is spoedig deur Bybelwetenskaplikes ook op tekste in die Bybel toegepas ${ }^{5}$. Jacobson (1992:108) wys egter daarop dat 'n deurwinterde strukturalis soos Lévi-Strauss (contra Leach) die toepasbaarheid van strukturele ontleding op die Bybel aanvanklik bevraagteken het. Barton (1996:105-106) voer twee redes aan waarom Bybelwetenskaplikes hierdie literêre strategie begin toepas het. Eerstens was hierdie ontwikkeling die gevolg van 'n ontnugtering deur die resultate (of gebrek aan resultate) van die tradisionele histories-kritiese benadering, en tweedens ' $n$ besef onder Bybelwetenskaplikes dat die tradisionele siening van die tekste in die Bybel nie rekening gehou het met moderne ontwikkelinge binne die literêr-wetenskaplike gemeenskap nie. House (1992:100) merk in hierdie verband selfs op dat "[s]tructuralism furthered [biblical] literary criticism's academic credibility by linking it with secular literary analyses and philosophy, where structuralism was already popular".

Die strukturalistiese bestudering van 'n teks in die Bybel het, net soos 'n soortgelyke bestudering van "algemene" literatuur, nie in die eerste plek ten doel

\footnotetext{
5 Een van die klassieke voorbeelde in hierdie verband is Barthes se lesing van Genesis 32 (vgl Barthes, 1977:125-141).
} 
om 'n nuwe (of selfs enige) betekenis aan 'n teks toe te skryf nie. In die woorde van Barton (1996:129): “ . . s structuralism is not in principle a method for uncovering new meanings; it is an explanatory framework to account for meaning that is already perceived".

Verder het die "suiwer" strukturalistiese benadering ${ }^{6}$ tot die tekste in die Bybel weinig, indien enigsins, kennis geneem van die resultate wat deur middel van tradisionele historiese metodes van ondersoek verkry is. Die skrywers van die Bybelteks en hulle bedoelings (intent), die historiese konteks, sowel as die "eerste lesers" was nie meer van belang nie. Van belang was die teks wat geskryf is en om strukturele konvensies voor te stel vir die huidige lees van daardie teks.

Hierdie ahistoriese ingesteldheid van die strukturalistiese benadering wat saamhang met die beklemtoning van die vorm van die teks, het daartoe gelei dat dit veral in die poëtiese tekste van die Ou Testament 'n toepassingveld gevind het ( $\mathrm{vgl}$ Prinsloo 1994). Die soeke na 'n betekenis in die vormlike aspekte van die teks sou egter nie tot die poëtiese tekste beperk bly nie. Die opkoms van narratologie (wat deur Oosthuizen [1994:84] beskryf word as 'n benadering "which may include various particular methods of narrative analy[s]is") het die weg geopen vir die toepassing van strukturalistiese en formalistiese insigte op die verteltekste in die Ou Testament. In hierdie studie word die onderskeid tussen strukturalisme en die "voorganger" tot hierdie benadering, formalisme, nie so rigied gehandhaaf nie (vgl House 1992:165). Vir 'n soortgelyke vervaging van die onderskeid kan verwys word na werk van Bar-Efrat (1980) en sy onderskeid tussen struktuurpatrone en die funksies daarvan. Die Postmodern Bible (PMB) (1995:70) meen "narratology ... grows in some way out of the structuralist impulse" en daar word selfs gepraat van "structuralist narratology" (PMB 1995:71). Vir 'n kort vergelyking tussen strukturalisme en formalisme, sowel as

\footnotetext{
6 Soos uit hierdie studie sal blyk, bestaan daar binne literêre kritiek weliswaar geen suiwer benadering tot 'n teks nie. Jacobson (1992:101) verwys selfs na strukturalisme as "an array of methods". Elke benadering toon invloede van ander benaderings. Met "suiwer" word hier bedoel 'n benadering wat die teks self as primêre (en dikwels enigste) fokus het. Soortgelyke benaderings word dikwels onder die noemers van teks-immanente, sinkroniese of "intrinsieke" benaderings tuisgebring.
} 
'n beoordeling van die bruikbaarheid van hierdie benaderings deur "die gereformeerde eksegeet" word verwys na Schultze (1988).

Bar-Efrat (1980) onderskei vier vlakke ${ }^{7}$ in die teks waarbinne elemente waarop die strukturele ontleding van die teks gebou kan word, mag voorkom. Hierdie vlakke word aangedui as (1) die verbale vlak, (2) die vlak van verteltegniek, (3) die vlak van die vertelde wêreld, en (4) die vlak van konseptuele inhoud. Bar-Efrat (1980:157-170) gee 'n uitgebreide uiteensetting en voorbeelde van hierdie vlakke waarvolgens struktuur in 'n teks bepaal kan word. Ek gee slegs 'n oorsig van sy beskrywing. Vir nog 'n oorsig van Bar-Efrat se uiteensetting kan verwys word na Kaiser en Silva (1994:77-79).

Op verbale vlak is aanduidings van die struktuur van 'n gedeelte opgesluit in woorde en frases. Dit kan insluit herhaling van woorde of frases, of geordende variasies van woorde en frases. Stilistiese elemente hoort ook by hierdie vlak tuis en kan ook 'n bydrae lewer tot die bepaling van struktuur. Die onderskeid wat Bar-Efrat (1980:158) op hierdie vlak tref tussen struktuur en tekstuur is vir hierdie artikel van belang, omdat ek aansluit by wat Bar-Efrat verstaan onder struktuur. Hy meld "[i]t [texture] consists of the small-scale relations among the subordinate and generally proximate parts of the narrative, whereas structure proper consists of the relatively large-scale relations among the main and possibly distant parts".

Wanneer gesoek word na strukturele merkers op die vlak van verteltegniek, word gelet op variasies in die vertelmetode. Voorbeelde hiervan sluit in: ' $n$ inset van die verteller teenoor dialoog van die karakters, uitgebreide beskrywing teenoor samevatting, asook vertelling teenoor beskrywing. Op die vlak van die vertelde wêreld, wat gebaseer is op die inhoud van die vertelling, word onderskeid getref tussen karakters en gebeure. Kenmerke eie aan bepaalde karakters, byvoorbeeld hulle identiteit, aard, asook rol in die vertelling, kan dien as aanduiding van struktuurmerkers. Die verhouding tussen

\footnotetext{
7 In 'n latere werk verminder Bar-Efrat (1997:197) hierdie vier vlakke na drie "strata". Vlakke (1) en (2) word hiervolgens saamgevoeg onder die stratum van taal. Vlakke (3) en (4) word behou (as strata 2 en 3), maar vlak (4) word genoem "the stratum of meanings". In die uiteensetting van die verskillende vlakke, hou ek ter wille van verduideliking by Bar-Efrat se aanvanklike (meer uitgebreide) uiteensetting. Wanneer hierdie vlakke later op die boek Daniël van toepassing gemaak word, sal met Bar-Efrat se latere onderskeiding van drie strata gewerk word.
} 
verskillende gebeure in die verhaal bepaal die "plot' van die verhaal. Die strukture van verskillende "plots" kan met mekaar vergelyk word, om byvoorbeeld ooreenkomste vas te stel, op voorwaarde dat die "plots" nie in algemene en abstrakte terme beskryf word nie. In aansluiting hierby kan wisseling in dramatiese struktuur (bv die intensifisering en verslapping in spanningslyn), asook temporele struktuur dien as aanduiding van die struktuur in 'n vertelling. Die laaste en mees arbritrêre vlak waaruit strukrurele patrone afgelei kan word, is die vlak van konseptuele inhoud. Op hierdie vlak word gepoog om basiese temas in die vertelling te onderskei. Bar-Efrat (1980:169) waarsku dat subjektiwiteit op hierdie vlak 'n groot gevaar is. Daar moet dus sorg gedra word dat die temas wat onderskei word, inderdaad inpas by die struktuur van die vertelling en nie by die struktuur wat die ontleder op die vertelling wil forseer nie. $\mathrm{Na}$ hierdie bespreking van die verskillende vlakke op grond waarvan struktuur in 'n vertelling bepaal kan word, onderskei Bar-Efrat (1980:170) na aanleiding van die herhaling van bepaalde strukturele elemente vier struktuurpatrone, naamlik 'n parallelle patroon (A-A'), 'n ringspatroon (A-X-A'), 'n chiastiese patroon (A-B-B'$A^{\prime}$ ) en 'n konsentriese patroon (A-B-X-B'-A'). Die onderskeiding van hierdie patrone gaan weereens saam met 'n waarskuwing dat hierdie praktyk nie oordryf moet word nie en dat die strukturele ontleding (struktuurpatroon) nie gebaseer kan word op elemente wat deels bekom is uit een van die bogenoemde vlakke (byvoorbeeld die verbale vlak) en deels uit een van die ander vlakke nie.

Die belang van hierdie strukturele benadering tot ' $n$ vertelteks word soos volg deur Bar-Efrat (1980:172) opgesom: “... it ... will provide us with a fuller and richer understanding of the narratives ... prove the unity of a given narrative ... [and] ... (serve) to express or accentuate meaning" (my kursivering).

\subsection{Strukturalistiese studies en die Ou Testament ${ }^{8}$}

Om die beredenering dusver te konkretiseer gee ek vervolgens twee voorbeelde ${ }^{9}$ van die toepassing van die formalistiese (narratologiese) en strukturalistiese

\footnotetext{
${ }^{8}$ Vgl Milne (1988:41-65) vir 'n breedvoerige bespreking van hierdie tema.

9 Combrink (1988) en Schultze (1988) verskaf ook 'n aantal voorbeelde van die toepassing van die strukturalistiese benadering op die teks van die Bybel.
} 
benaderings tot 'n teks uit die Ou Testament. Die eerste voorbeeld sluit nouer aan by Bar-Efrat se siening aangaande (narratologiese) struktuur, terwyl die tweede gesien kan word as 'n voorbeeld nader aan "suiwer" strukturalisme. Hierdie twee voorbeelde dien onderskeidelik as manifestasies van wat PMB (1995:76) beskryf as "low structuralism" (in die geval van Fishbane) en "high structuralism" (in die geval van Freeman). Hierdie onderskeid val verder saam met wat Vorster (1982) soos aangehaal deur Combrink (1988:134) bestempel as strukturele en strukturale eksegese.

Fishbane (1982:191) stel hom ten doel om 'n ontleding te gee van beide die formele struktuur en narratiewe styl van 1 Samuel 3 (die roeping van Samuel), om sodoende die geïntergreerde vlakke van betekenis bloot te lê. Eerstens word aangetoon dat die historiese en literêre elemente in die teks geïntegreerd is, soveel so dat "there is no historical interpretation of I Samuel 3 which is not also a literary interpretation - and vice versa" (Fishbane 1982:192193). Tweedens word twee komplementêre interpretasies aan die chiastiese (eerder konsentriese?) struktuur (A-B-C-B'-A') van die hoofstuk toegeken. Enersyds fokus die struktuur die aandag op die sentrale Godspraak (C-vv 10-15) waardeur die opening en die slot van die hoofstuk in perspektief geplaas word. Andersyds kan die struktuur ook dui op 'n dramatiese ontwikkeling tussen $A$ (vv 1-3) en A' (vv. 19-21).

Fishbane (1982:196 ev) ontleed voorts die verskillende elemente binne hierdie "chiasme". Hy toon aan hoe stilistiese tegnieke soos herhaling (van klanke [alliterasie en assonansie], woorde en sinsnedes), woordspelings en sinspelings, asook stylfigure soos ironie en kontras, die tematiese ontwikkeling in die verhaal aandui en ondersteun. Fishbane (1982:203) kom tot die volgende gevolgtrekking: "What is ... striking ... is the way purely formal phonemic repetitions complement levels of meaning achieved by other means." (my kusivering)

Die positiewe aspek van Fishbane se benadering is dat daar nie met ' $n$ ontleding van die stilistiese en strukturele eienskappe van die teks volstaan word nie, maar dat hierdie eienskappe ook geïnterpreteer word. Verder is hierdie interpretasie geskoei op die wisselwerking tussen vorm en inhoud en is die vorm 
nie die enigste faktor wat in aanmerking geneem word by interpretasie nie. Dit mag selfs wees dat Fishbane vorm ondergeskik aan inhoud maak, omdat hy meen dat fonemiese herhaling dien as komplement tot ander vlakke van betekenis.

'n Voorbeeld van 'n ontleding van 'n teks in die Ou Testament wat meer vanuit 'n "suiwer" strukturalistiese benadering voortkom, is dié van Freeman. Hy gee 'n baie beskrywende titel aan hierdie bydrae, naamlik Samson's dry bones: $A$ structural reading of Judges 13-16. Die "droeë bene" verwys na die onderliggende struktuur in die vertelling. Freeman (1982:147-149) wys eerstens daarop dat met behulp van tradisionele eksegetiese metodes aangetoon kan word dat 'n bepaalde "oppervlakstruktuur" in die hele boek Rigters bestaan. Vanuit hierdie vertrekpunt gee Freeman (1982:150-153) 'n analise van die dieptestruktuur in die Simsonvertellings (Rigters 13-16). Hy onderskei elf onderafdelings ("blocks of action") in die Simsonsiklus, wat elkeen 'n bepaalde onderliggende struktuur vertoon. Hierdie struktuur bestaan in die meeste gevalle uit die chronologiese opvolging van die volgende elemente: ' $n$ bedreiging of handeling van destruksie (A); 'n handeling van persoonlike genot $(B)$; 'n vraag $(C)$; en 'n handeling van verloëning (D). In hierdie patroon word 'n progressie gesien van brutale manlike vertoon (A), na 'n meer gespesialiseerde sensoriese aktiwiteit (B), na 'n meer gesofistikeerde handeling van die brein $(C)$, terwyl alles uitloop op verloëning (D).

Wat opval is dat hierdie interpretasie bloot konsentreer op die vorm wat in die teks blootgelê is en nie op die inhoud van die teks nie. Die inhoud is ondergeskik aan die onderliggende dieptestruktuur en moes net hierdie dieptestruktuur help blootlê. Teen hierdie vorm van klem op die teks as sodanig kom Snyman (1996) in verset, wanneer hy 'n struktureel-historiese ondersoek in die plek daarvan voorstel. Die geïdentifiseerde dieptestruktuur help volgens Freeman (1982:155) in die eerste plek die leser om die verhale oor Simson te geniet, sonder om te vrees dat die karakter se optrede die morele balans wat hy as "nasireër" moet handhaaf, sal omvergooi: "this story moderates its subject's rage by means of its own rage for esthetic order, thus protecting the reader from ungovernable emotion" (Freeman 1982:155). 
Hierdie struktuur help tweedens om die leser te verseker dat ten spyte van die optrede van die hoofkarakter (Simson), Jahwe in beheer van die situasie is. Derdens help hierdie indeling om die gewone leser met Simson te laat identifiseer, omdat die patroon van brute krag, sensoriese handeling en intellektuele kapasiteit eie is aan elke mens. Vierdens meen Freeman (1982:156-157) dat hierdie vertelling se dieptestruktuur die spanning tussen die mens se strewe na outonomiteit en sy vrees vir uitsluiting deur 'n groep uitbeeld. Die laaste afleiding wat Freeman (1982:158) op grond van sy dieptestruktuuranalise makk, hou verband met die drie (vreemde) vroue in Simson se lewe: "Whatever lure may lie in a mixed marriage, the author of Judges persuades us that it cannot gain us a helpmeet for our private expression."

Alhoewel hierdie laaste stelling van Freeman en veral die wyse waarop hy daarby uitkom gebruik kan word om groot dele van sy betoog te dekonstrueer, word dit daar gelaat.

Uit hierdie enkele opmerkings aangaande die strukturele benadering tot tekste in die algemeen en die teks van die Bybel in die besonder, is een saak redelik duidelik: die "suiwer" strukturalistiese benadering tot 'n teks laat geen (of weinig) plek vir die historiese dimensie van die teks (vgl Ray 1984:111). Teen hierdie leemte in die "suiwer" strukturalistiese benadering het sommige Bybelwetenskaplikes kritiek uitgespreek (vgl Deist 1994, 1996). Snyman (1996) het hierdie kritiek ernstig opgeneem en poog om 'n eksegetiese model te ontwikkel wat die strukturele, sowel as historiese dimensies van die teks in berekening bring. Snyman was nie die eerste om in hierdie rigting te werk nie. Barton (1996:130 ev) toon aan hoe Loader in sy boek Polar structures in the book of Qohelet (1979) ten spyte van die gebruik van strukturalistiese benaminge "merely adds structuralist ideas to the historical-critical tool-box".

In die huidige artikel gaan die insigte vanuit 'n bepaalde strukturele benadering (by name narratiewe struktuur soos verstaan deur Bar-Erfat), soos dit hierbo kortliks belig is, van toepassing gemaak word op die boek Daniël. 


\section{4. 'N STRUKTUUR VIR DIE BOEK DANIËL}

\subsection{Inleidende opmerkings aangaande struktuur in die boek Daniël}

Opvallend by die meeste strukturele indelings van die boek Daniël is dat voorkeur verleen word aan indelings op grond van literatuursoort ( $\mathrm{vgl}$ Montgomery 1927:89; Collins 1984:31, Davies 1985:11 en Milne ${ }^{10}$ 1988). Die eerste ses hoofstukke (1-6) word daarom as "vertellings" onderskei van die laaste ses hoofstukke (7-12), wat gegroepeer word onder die noemer "visioene". Daar is aansienlik minder indelings wat ook erns maak met die struktuurpatroon wat opgesluit is in die twee tale waarin die boek geskryf is (vgl. egter Baldwin 1978). Die twee tale (Hebreeus [in 1-2:4a; 8-12] en Aramees [in 2:4b-7:28]) reflekteer ook nie die onderskeid op grond van verskillende literatuursoorte nie.

\section{2 'n Struktuurvoorstel vir Daniël 1}

Struktureel word Daniël 1 deur kommentatore in drie tot vyf dele verdeel. Collins (1984:43-44) neem vv 1-7 as inleiding (bestaande uit twee dele, naamlik 'n historiese inleiding [vv 1-2] en die bekendstelling van die hooffigure [vv 3-7]), met vv. 8-16 (die weiering van die koning se kos) 'n onafhanklike verteleenheid en vv. 17-21 as samevatting ${ }^{11}$. Dit is opvallend dat vv. 8-16 in hierdie indeling sentraal staan. Baldwin (1978:77-85) se driedelling van hoofstuk 1 sien soos volg daar uit: vv 1-2 is ' $\mathrm{n}$ historiese inleiding, vv 3-7 is die bekendstelling van die gevangenes, en vv 8-21 word saamgevoeg onder die noemer "to conform or not to conform". Die laaste gedeelte vorm op grond van klimaktiese opbou die sentrale fokus van die hoofstuk.

Porteous (1965:25-33) stel 'n vierdeling van die eerste hoofstuk van die boek Daniël voor waarin vv 1-2 weereens die toneel skets; vv 3-5 hierdie inleidende skets verder uitbrei; vv 6-17 die held van die boek en sy metgeselle voorstel, sowel as 'n probleem en die ontknoping daarvan weergee, en vv 17-21 die goddelike beloning vir die getrouheid van sy dienaars verhaal. Montgomery (1927:113) bied die volgende vierdeling van hierdie hoofstuk aan: vv 1-2 verhaal

\footnotetext{
${ }^{10}$ Milne (1988) maak 'n toepassing van die werk van Propp op die vertellings in Daniël 1-6.

11 Vgl ook Collins (1993:129-130) vir 'n soortgelyke indeling met meer uitgebreide bespreking.
} 
die wegvoering na Babel, vv 3-7 vertel van die opleiding van Daniël en sy drie vriende; vv 8-17 handel oor hulle vroomheid, en vv 18-21 oor die erkenning van hulle wysheid deur Nebukadnéser.

Meer resente studies, wat ook erns maak met die literêre aspekte van die teks, bied voorstelle vir ' $n$ vyfdeling van hierdie hoofstuk aan. Burden (1987:212) wys op die konsentriese struktuurpatroon wat deur 'n vyfdeling van die hoofstuk blootgelê word: vv 1-[2] is ' $n$ historiese mededeling (A), vv 3-7 bevat die koninklike bevel (B), vv 8-17 vertel van Daniël se wyse besluit en die implementering daarvan (C), vv 18-20 verhaal die rapport aan die koning (B'), en $\checkmark 21$ is weer ' $n$ historiese mededeling ( $\left.A^{\prime}\right)$. Volgens hierdie indeling vorm vv 8-17 die kritiese draaipunt van die hoofstuk. Goldingay (1993:298) maak ook erns met hierdie struktuurpatroon in sy verklaring van die eerste hoofstuk, alhoewel hy na hierdie patroon as 'n chiasme verwys (vgl ook Goldingay 1989a:8). Weereens vorm vv 8-16 die sentrale fokus, wat saam met die ander elemente "the story's plot tension and resolution" aandui.

Op die oog af mag dit lyk asof hierdie laaste voorstel met betrekking tot die struktuur van Daniël 1 net gebaseer is op tematiese ooreenkomste, of in die woorde van Bar-Efrat die stratum van die vertelde wêreld. Indien dit die geval sou wees, sou hierdie indeling baie subjektief wees. Hierdie subjektiwiteit kan tot 'n mate getemper word indien herhalingspatrone (ooreenstemmende fenomene op die taalvlak) wat hierdie struktuurvoorstel staaf, in die teks geïdentifiseer kan word. Longman (1993:98-99) het juis waardering vir Fokkelman se identifisering van 'n "chiastiese" struktuur in Gen 11:1-11, op grond van die feit dat hierdie struktuurontleding gebaseer is "on related words and not the general thought of the units". Bar-Efrat (1997:197) merk in hierdie verband op dat die stratum van die vertelde wêreld gebaseer is op en bepaal word deur die vorige stratum, naamlik die stratum van taal. Vir die doeleindes van hierdie artikel fokus ek net op die struktuur soos wat dit bepaal kan word op grond van Bar-Efrat se eerste en tweede strata en wys vervolgens op enkele herhalingspatrone in hierdie konsentriese patroon. 
In die "buitenste" komponente van die patroon (vv 1-2 [A] en v. 21 [A']) kom die volgende herhaling in die stratum van taal voor ${ }^{12}$ : lidwoord + שנת + telwoord + persoonsnaam + מלד ("in die [getal] jaar van koning [persoonsnaam]") ( $v v 1 ; 21)$. In die stratum van die vertelde wêreld is daar 'n verdere ooreenkoms tussen hierdie komponente, deurdat die woorde in vv 1-2 verwys na die begin van die ballingskap, terwyl die woorde van $v 21$ verwys na die einde van die ballingskap. Dit val verder op dat die woordorde in die eerste sin van die boek die klem juis wil plaas op die datum, deurdat die sin met 'n datum in plaas van 'n werkwoord begin. Die derde stratum van Bar-Efrat se onderskeiding in verteltekste, naamlik die stratum van betekenis, word nie hier behandel nie, alhoewel in $v 2$ ' $n$ goeie voorbeeld is van wat onder hierdie noemer verstaan kan word, naamlik die betekenis wat opgesluit is in die feit dat die eerste $\sin (v 2)$ waarvan die woordorde "normaal" (WSO) is, juis God as handelende subjek het.

Die volgende stel komponente van die konsentriese patroon ( $v v$ 3-7 [B] en vv 17-20[B']) vertoon die volgende ooreenkomste (herhalingspatrone) in die stratum van taal:

- In vv 3 en 18 val die herhaling van die uitdrukking ליאמר המלך ... להביא ("en die koning het gesê ... om te bring") op.

- In vv 4 en 17 is daar 'n ooreenkoms tussen die uitdrukkings ספר ...

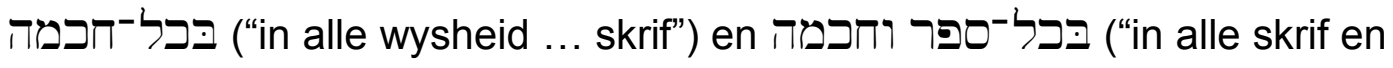
wysheid"), terwyl die woord מדע ("vernuf") ook in albei verse voorkom.

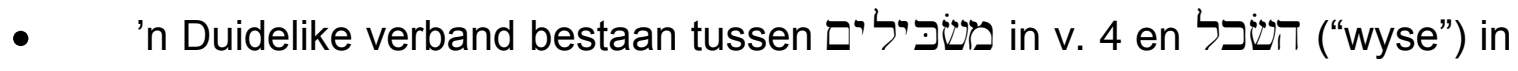
v 17.

- ' ' ' ("staan voor die koning").

12 In hierdie vyf "blokke" kom ook woorde en uitdrukkings voor wat as "skakels" tussen hierdie blokke dien, byvoorbeeld die gebruik van "noem/plaas" (Hebr שים) as (ironiese?) verbinding tussen B (v 7) en C (v 8), asook die voorkoms van die woord מקצ (vv 5, 15, 18) in B, C en B' en die voorkoms van נתץ (vv 2, 9, 12, 16, 17) in A, C (3X) en B'. Die paradigmatiese herhaling van eiename, asook ampstitels vorm verdere skakels tussen hierdie vyf blokke. Ek bepaal my egter hieronder net by herhalingspatrone wat uniek is aan die blokke waarin dit voorkom, byvoorbeeld in $A$ en $A^{\prime}$ of $B$ en $B^{\prime}$. 
In die stratum van die vertelde wêreld is die skakel tussen B en B' die fokus op die vier vriende ( $\vee 17$ kan byvoorbeeld logies [en grammatikaal] volg op $\vee 7$ ), asook die begin en die einde van die "proeftydperk" aan die hof ( $\mathrm{g} / \mathrm{v} v$ 4,5 en $\mathrm{v}$ 18). Ek meen dat hierdie ooreenkomste in die strata van taal en die vertelde wêreld die konsentriese struktuur van hoofstuk 1 ondersteun. Die sentrale deel van die hoofstuk is dan die oorblywende vertelling in vv 8-16 vanweë die sentrale plek wat dit inneem in die konsentriese struktuur van die hoofstuk (vgl Fishbane 1982). Hierdie sentrale deel in Daniël 1 word verder onderskei van die ander dele van hoofstuk 1 , deurdat die verteltegniek verander van beskrywing deur die outeur na dialoog deur die karakters.

Nadat aangetoon is dat die konsentriese patroon wat vir hoofstuk 1 voorgestel word, geverifieer kan word deur herhalings op verbale vlak, asook die vlak van die vertelde wêreld, gaan vervolgens gelet word op voorstelle wat met betrekking tot die struktuur van Daniël 2-7.

\section{3 'n Struktuurvoorstel vir Daniël 2-7}

Daar is reeds genoem dat hierdie studie erns wil maak met beide die onderskeid in taal en literatuursoort wat in die boek Daniël aangetref word. Om hierdie rede word die Aramese dee/ van die boek in sy finale vorm (hoofstukke 2-7) hier apart bespreek. Die feit dat hierdie hoofstukke in die huidige (finale) redaksie in dieselfde taal geskryf is, onderstreep die verband wat tussen hierdie hoofstukke bestaan. Hierdie verband is in die verlede soms misgekyk vanweë die feit dat navorsers dikwels net op literatuursoorte gefokus het. So is die ooreenkoms tussen hoofstukke 2 en 7 byvoorbeeld deur Montgomery (1927:89) gering geskat vanweë die verskille in literatuursoort.

Baldwin (1978:59-60) verwys in haar kommentaar na die strukturele verband tussen die hoofstukke van die Aramese deel van die boek, soos dit deur Lenget (1972) beskryf is. Hiervolgens bestaan 'n ooreenkoms tussen hoofstukke 2 en 7, 3 en 6 , asook 4 en 5 . Die ooreenkoms wat bestaan tussen hoofstukke 2 en 7 van die boek Daniël is voor Lenglet reeds deur Porteous (1965:13) en Montgomery (1927:282-283) raakgesien, alhoewel hulle verkies om die klem te laat val op die tweedeling van die boek aan die hand van die verskillende 
literatuursoorte. Porteous (1965:13) merk op: "The first of the visions (ch. 7) has its parallel in Nebuchadnezzar's dream (ch. 2) and links the two parts together." Lenglet (1972) bespreek die konsentriese strukturering van die Aramese gedeelte van die boek Daniël in detail. Sy voorstel het gelei tot verdere studie met betrekking tot die hoofstukke wat hy as sentraal in die gedeelte geïdentifiseer het (vgl Shea 1985, se werke oor Daniël 4 en 5). Volgens Lenglet (1972:187) vorm hierdie hoofstukke (Daniël 4 en 5) in die sentrum van die Aramese deel 'n eenheid rondom een tema: God, die Here van die geskiedenis, wil as sodanig erken word deur die prinse van die wêreld, omdat dit $\mathrm{Hy}$ is wat hulle mag gee en dit wegneem.

Lenglet (1972:171-187) bespreek 'n aantal ooreenkomste tussen die ooreenstemmende Aramese hoofstukke waarvoor hy 'n konsentriese struktuur voorgestel het. Onlangs het Albertz (2001:178) hierdie bespreking van Lenglet aangehaal as deel van 'n bewys vir die literêre eenheid van die Aramese gedeelte van die boek. Alhoewel Lenglet meer klem plaas op die vlak van die vertelde wêreld, gee hy ook voorbeelde wat verband hou met die verbale vlak. Dit behels onder meer verbatim herhalings van woorde en frases in Dan 2 en 7, Dan 3 en 6, asook Dan 4 en 5.

Lenglet (1972:171-172) identifiseer met betrekking tot Dan 2 en Dan 7 onder andere die volgende: verwysings na 'n "droom" en die "interpretasie" daarvan, asook die verwysing na 'n "ewige koninkryk". Met betrekking tot Daniël 3 en 6 lys Lenglet (1972:183-184) 'n groter aantal verbale ooreenkomste. Hierdie ooreenkomste sluit in: Jode wat die koning "nie respekteer nie", hulle teenstanders wat "nader" tot die koning, die koning wat "vinnig opstaan", "God wat 'n engel stuur" en die Jode wat "voorspoedig" is na hulle noue ontkoming. In Daniël 4 en 5 word weereens minder verbale ooreenkomste gelys as wat in die teks bestaan (vgl Lenglet, 1972:186). Hierdie ooreenkomste sluit in: die "wyses" van die koning wat nie in staat is om te "interpreteer" nie, asook Daniël "in wie die gees van die heilige gode woon" wat wel in staat is om te "interpreteer".

Aangesien Lenglet sy voorstel met betrekking tot die struktuur van die Aramese gedeelte van die boek Daniël goed beredeneer en dit ook as sodanig aanvaar word, word nie verdere bespreking daaraan gewy nie. Die struktuur wat 
blootgelê is, reflekteer dieselfde patroon as wat met betrekking tot Daniël 1 opgemerk is, naamlik 'n konsentriese struktuur waarin die klem volgens Lenglet (1972:188) op die middelste (sentrale) deel val (Dan 4 en 5). Dit is die klimaks van die boodskap en dui daarop dat die God van die hemel as sodanig deur aardse regeerders erken wil word (vgl Baldwin, 1978:60).

Die teologiese betekenis van die twee hoofstukke wat in die sentrum van die Aramese gedeelte staan, is raak deur Redditt $(1999: 86,101)$ opgesom. Hy beskou Daniël 4 as verteenwoordigend van 'n standpunt dat "the best one could hope for was that foreign kings acknowledge God and be just and merciful to Judeans in their kingdoms". 'n Teenoorgestelde standpunt word in Daniël 5 bespeur waarin die redaktor "abandoned hope that the foreign king would acknowledge God". Om hierdie rede word die godslaterende koning om die lewe gebring. Die sentraliteit van Daniël 4 en 5 word ook deur Collins (1993:45) onderskryf wanneer hy opmerk: "Daniel 4 and 5 are more closely bound together than the other stories".

Nadat gewys is op die herhaling van die konsentriese struktuur van die inleidende Hebreeuse deel van die boek (Daniël 1) in die groter Aramese deel (Daniël 2-7), verskuif die aandag nou na die groter Hebreeuse deel (Daniël 8-12).

\section{4 'n Struktuurvoorstel vir Daniël 8-12}

Die langer Hebreeuse deel van die boek Daniël word gewoonlik onder die noemer "visioene" tuisgebring, alhoewel Daniël 9 nie in alle opsigte inpas by so 'n beskrywing nie. Indien Daniël 9 vir die oomblik buite rekening gelaat word, ${ }^{13}$ dan lyk dit op die vlak van die vertelde wêreld asof Daniël 8 en Daniël $10-12^{14}$ albei visioene is wat betrekking het op 'n tweede-eeuse konteks en in besonder die tyd van Antiogus Epiphanes (vgl Collins 1993:343, 403).

Weereens sou dit op grond van die vereistes wat Bar-Efrat stel vir die aantoon van struktuur nie voldoende wees om bloot op grond van die

\footnotetext{
13 Hiermee word nie gesê dat hierdie hoofstuk geen verband met Daniël 8 en Daniël 10-12 het nie (vgl Collins 1993:359).

14 Dit het gemeenplaas geraak om Daniël 10-12 saam te groepeer (vgl Collins, 1993:371), alhoewel die slot (Dan 12:5-13) in sommige kringe as sekondêr beskou word (vgl Redditt 1999:165).
} 
ooreenkomste op die vlak van die vertelde wêreld 'n bepaalde struktuurpatroon bloot te lê nie. Daarom word hierdie hoofstukke wat die buitenste grense van die groter Hebreeuse deel vorm ook bestudeer met die oog op moontlike ooreenkomste op verbale vlak. Hiervolgens kan die volgende gelys word:

- (8:1; 10:1 - "in die derde jaar ... van persoonsnaam ... die koning");

- (8:2; 10:4 - "Ek was by");

• (8:3; 10:5 - "Ek het my oë opgelig en gesien en kyk een [objek]");

- • voorsetsel (8:9; 11:16 - "na / in die pragtige [land]"15);

- $\quad$ getalle (8:14; 12:11,12 - "2300"; "1290", "1335”);

- פרם (8:20; 10:20, 11:2 - Perse);

- $\quad \quad$ Iי (8:21; 10:20, 11:2 - Griekeland);

- $\quad$ מרמה (8:25; 11:23 - bedrog);

- $\quad$ (ה) (1)

Hierdie voorbeelde, wat selfs nog verder uitgebrei kan word, wys in die rigting van ooreenkomste tussen Daniël 8 en Daniël 10-12 op verbale vlak.

Wanneer die aandag verskuif na Daniël 9 en fokus op die vlak van die vertelde wêreld val, is dit duidelik dat hierdie hoofstuk uit twee onderskeibare elemente bestaan. Die eerste is ' $n$ lesing en interpretasie van ' $n$ teks geneem uit die profeet Jeremia en wat betrekking het op die getal van 70 jaar (9:1-3; 9:2027). Die tweede element is 'n lang gebed van Daniël (9:4-19). Redditt (1999:147-148) lys 'n aantal aspekte wat die gebed van die res van die hoofstuk onderskei. Vir die huidige bespreking is dit nie ter sake of die gebed 'n sekondêre toevoeging is, al dan nie, omdat selfs diegene wat die gebed beskou as geïnkorporeer by die res van die hoofstuk tydens die aanvanklike komposisie

${ }^{15}$ Die woord "land" kom net in 11:16 voor, op grond waarvan dit ook vir 8:9 voorgestel word. 
van die hoofstuk (en dus nie op 'n latere tydstip nie) erken dat die gebed 'n eiesoortige karakter vertoon (vgl Collins 1993:347-348).

Wat wel hier van belang is, is die strukturering van die hoofstuk. Daar is reeds op gewys dat op die vlak van die vertelde wêreld 'n ooreenkoms bestaan tussen Daniël 9:1-3 ('n teks van die profeet Jeremia) en Daniël 9:20-27 ('n interpretasie van daardie teks). Vervolgens word nagegaan of 'n soortgelyke ooreenkoms tussen hierdie komponente van die hoofstuk op verbale vlak gevind kan word. Die volgende ooreenkomste kom wel voor:

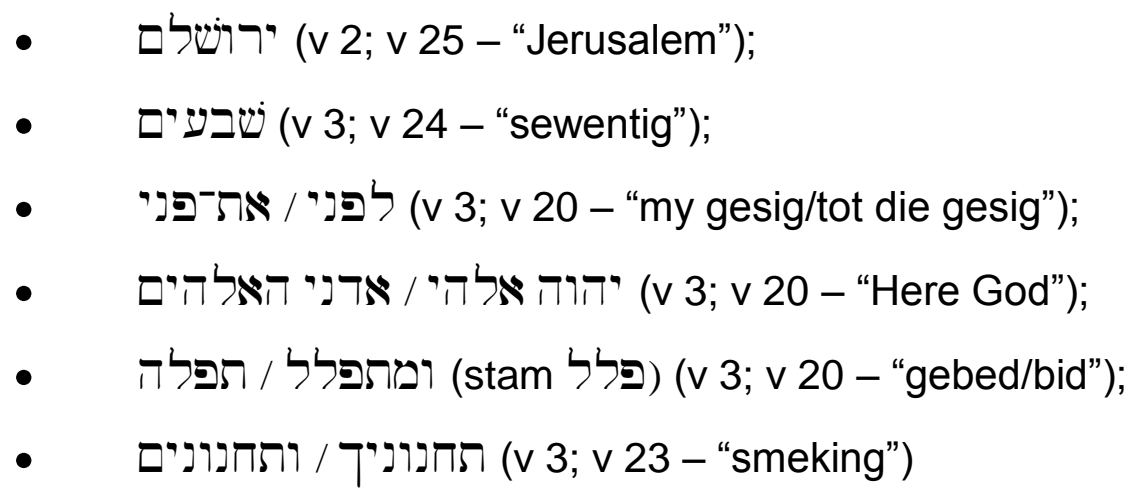

Alhoewel enkele van hierdie woorde ook in die gebed van Daniël voorkom, herinner hierdie herhalings aan wat Alter (1987:28) beskryf as "resumptive repetition". Hieruit blyk dit dat 'n konsentriese struktuur ook in die langer Hebreeuse deel van die boek Daniël voorkom.

Indien die argumentasie dusver water hou, beteken dit dat die konsentriese struktuur van Daniël 1 herhaal word in die daaropvolgende Aramese en Hebreeuse dele van die boek. Verder, indien Lenglet korrek is dat die sentrale dele van 'n konsentries-gestruktureerde teks klem dra, dan sou gevra kon word waarom Daniël 4 en 5 enersyds, en die gebedsdeel in Daniël 9 andersyds so belangrik is. Vervolgens word hieraan aandag gegee wanneer die saak rondom 'n boodskap in die boek Daniël aan die orde gestel word.

\section{BOODSKAP(PE) IN DIE BOEK DANIËL}

In hierdie gedeelte van die studie word dit wat reeds met betrekking tot die struktuur van die boek Daniël opgemerk is, in verband gebring met 'n boodskap 
(of boodskappe) wat die boek weergee. Eerstens word gelet op voorstelle wat reeds aan die hand gedoen is in hierdie verband. Sommige van hierdie voorstelle bevat meer ahistoriese teologiese afleidings, terwyl ander groter erns maak met met die tweede-eeuse sosio-historiese konteks van die boek. Vervolgens word die struktuurvoorstel wat hierbo ontwikkel is, gebruik om teologies- en sosiologies-georiënteerde boodskappe in die boek te probeer blootlê.

\subsection{Bestaande voorstelle aangaande boodskappe in die boek Daniël}

Enkele ouer teologiese werke wat uitgebreide aandag gee aan die teologiese riglyne in die boek Daniël sluit in die kommentaar van Montgomery (1927:78-87) en die teologieë van die Ou Testament deur Eichrodt $(1964,1967)^{16}$ en Von Rad (1965:308-315), terwyl die inleidings tot die Ou Testament van Eissfeldt (1965:528) en Harrison (1969:1105-1134) weinig aandag aan hierdie saak gee.

Childs (1979:613) merk met betrekking tot insigte in die teologiese riglyne wat die boek Daniël bied op dat hierdie insigte nie proporsioneel met ander navorsing oor die boek Daniël toegeneem het nie. Childs (1989) het self egter nie veel erns gemaak met die teologiese insigte wat die boek Daniël bied nie en in sy Old Testament Theology in a Canonical Context figureer die boek Daniël by wyse van verwysing slegs sewe keer. Hierdie verwysings kom voor in Childs se bespreking van die volgende temas: geskiedenis as wyse van God se selfopenbaring ( $\mathrm{vgl}$ Childs 1989:36, 37); die verbod om 'n beeld of afbeelding van God te aanbid (vgl Childs 1989:67); die weermag as een van die elemente wat 'n rol gespeel het in die gewone lewe van Israel en dan veral die oorlogsbeelde wat met betrekking tot die eindtyd gebruik word (vgl Childs 1989:185); die betrokkenheid van God by die aardse lewens van mense (vgl Childs 1989:200); en die apokalips as 'n radikalisering van die belofte van oordeel en verlossing (vgl Childs 1989:241). Die mees omvangryke hantering van die boek Daniël by

${ }^{16}$ Eichrodt se teologie van die Ou Testament neem as vertrekpunt die verbond as die sentrale lyn in die Ou Testament (vgl Eichrodt 1964:36). Binne hierdie skema word die boek Daniël veral betrek by die bespreking van die universele aspekte van die oordeel van God (vgl Eichrodt 1964:469-471); die transendentalisasie van die redding (vgl Eichrodt 1964:487-489); die engele as dienaars van Jahwe (vgl Eichrodt 1967:194-202); die samestelling van die wese van die mens (vgl Eichrodt 1967:131-147); en die idee van onsterflikheid (vgl Eichrodt 1967:509-517). 
Childs word aangetref in sy bespreking van Israel se lewe onder bedreiging. Die bedreiging word in hierdie boek uitgedruk deur beelde wat grens aan die demoniese. Die getroues word in die aangesig van hierdie bedreiging uitgebeeld met die rug teen die muur, terwyl gehoop word op hulp van God, die enigste bron van redding (vgl Childs 1989:231).

'n Meer omvattende bespreking van die teologiese riglyne (temas) in die boek Daniël is die bespreking van "groot [teologiese] temas" in die boek Daniël deur Goldingay (1989b). Hierdie boek word nie hier volledig bespreek nie, maar enkele fokusareas word uitgelig. $\mathrm{Na}$ ' $\mathrm{n}$ inleiding waarin gefokus word op die twee agtergronde tot die boek Daniël, bespreek Goldingay (1989b:11-20) getrouheid as tema. Eendersyds word die getrouheid van die helde in die eerste deel van die boek bespreek as getrouheid in lewenstyl (Dan 1), getrouheid in die onderhouding van die godsdiens (Dan 3) en getrouheid in gebed (Dan 6) (Goldingay, 1989b:12-18). Hierdie getrouheid word telkens deur God beantwoord (honored) by wyse van verlossing. Hierdie lyn van God se getrouheid figureer egter nie so sterk wanneer die tema van getrouheid in aanbidding (worship) (Dan 11) aan die orde kom nie. Goldingay (1989b:18-20) verdiskonteer die tweede eeuse agtergrond tot hierdie hoofstuk goed en kom tot die volgende (christologiese) gevolgtrekking: "[t]he visions in Daniel ... encourage us to look for deliverance after death if not before it."

'n Volgende tema wat Goldingay (1989b:21-32) belig is die konflik tussen die gesag van God en die gesag van mense (veral dié in regeringsposisies). Hierdie afdeling, wat net op die vertellings in Daniël 1-6 fokus, bespreek die hoofstukke wat hierbo uitgelig is as die sentrale hoofstukke in die konsentriese struktuur van Daniël 2-7 (hfste 4 \& 5) as manifestasies van hierdie tipe konflik. Die saak wat hierdie hoofstukke wil tuisbring is dat God ook mag het oor maghebbers. Goldingay (1989b:30-32) betrek ook die verhale van Daniël 3 en 6 by sy argument. Die feit dat die regeerders in hierdie hoofstukke op die ou einde tog weer probeer om hulle gesag te laat geld by wyse van die uitvaardiging van 'n edik ten gunste van God (vgl 3:29; 6:27), word deur Goldingay misgekyk (vgl egter Fewell 1991:57, 118). 
Die sentrale hoofstuk in die tweede deel van die boek Daniël (hoofstuk 9), soos hierbo blootgelê deur die konsentriese struktuurpatroon, word deur Goldingay (1989b:45-57) hoofsaaklik hanteer wanneer hy God en gebed as verdere teologiese tema in die boek Daniël onderskei. Eendersyds span Goldingay (1989b:46-47) hierdie hoofstuk in om die karakter van God te beskryf aan die hand van die begrippe חסד ("goedertierenheid") (9:4) en אממת ("waarheid") (9:13). Andersyds gebruik Goldingay (1989b:48-49, 52-55) die gebed van Daniël as model vir gebedsgesindheid en gebedsinhoud (veral ten opsigte van skuldbelydenis en beroep op God se genade). Die vraag wat in hierdie hoofstuk ontstaan as gevolg van die bemiddelde en onbevredigende antwoord wat Daniël kry, laat Goldingay grootliks onbeantwoord.

Ander teologiese temas wat Goldingay in die boek Daniël vind sluit in: Goddelike en menslike insig in gebeure en voorspellings; die rol wat "hemelse" magte en hulle verteenwoordigers speel in die wêreldgeskiedenis; teologiese perspektiewe op die geskiedenis; godsdienstige krisistye; en die einde. Hierdie temas word bespreek aan die hand van verwysings na verskillende hoofstukke van die boek Daniël. Hierdie veelheid van teologiese temas wat Goldingay identifiseer, is in lyn met literêre kritici se beklemtoning van meerdere temas in 'n literêre werk (vgl Ryken \& Longman 1993:23). Literêre kritici wat algemene literatuur bestudeer is nie baie opgewonde wanneer Bybelwetenskaplikes wat literêre studies van die Bybel aanbied, soveel klem plaas op 'n enkelvoudige tema of doel in 'n Bybelboek nie. Die soeke na 'n bepaalde tema (of teologie) in 'n boek loop hiervolgens die gevaar van reduksionisme.

Natuurlik is dit nie moontlik (of selfs wenslik) om die Ou Testament, of 'n bepaalde boek in die Ou Testament, te reduseer tot 'n enkele tema nie, maar om aan die ander kant die belangrike besinning binne die vakgebied Teologie van die Ou Testament bloot ' $n$ saak te maak van "soveel hoofde, soveel sinne", is ook nie gewens nie. Brueggemann (1997:5), wat Teologie van die Ou Testament sien as "engaged in the process of thematization", het gelyk wanneer hy opmerk dat "[e]ither the thematization is so specific that it omits too much, or so inclusive as to be meaningless". In 'n poging om vanuit die struktuur van die teks hierdie problematiek te ondervang, word die geïdentifiseerde sentrale hoofstukke in die 
twee dele van die boek Daniël hieronder as vertrekpunt geneem vir die identifisering van die teologiese hooftemas in die boek.

In sy boek Daniël probeer Davies (1985: 81-88) die gebrek aan teologiese besinning oor die inhoud van die boek Daniël aanspreek. Eerstens wys Davies (1985:81) daarop dat die twee agtergronde tot die boek Daniël (die diaspora, asook die verdrukking in Palestina) daartoe lei dat twee onderskeibare, maar ook harmoniseerbare, teologiese lyne bespeur kan word. Davies se voorstel met betrekking tot die teologie van Daniël fokus veral op die aard van God, wat bespreek word onder die volgende subopskrifte: die name vir God (Davies 1985:82); God en ander gode (Davies 1985:83); die God van Israel (Davies 1985:84); en die God van die geskiedenis (Davies 1985:86).

Met betrekking tot die name vir God wat in die boek Daniël gebruik word, maak Davies (1985:83) die afleiding dat hierdie name versigtig gekies is om daardeur die veelsinnige (en soms dubbelsinnige) verhouding tussen God, die Jode en die heidense koning uit te druk. Davies (1985:84) se afleiding aangaande God en ander gode in die boek is dat die boek Daniël nie handel oor afgodery nie, maar oor die politieke mag van regeerders. Davies (1985:84) som op: "it is the divine claims of kings which have caused the conflict with Jewish religion, not the claims of other deities."

In sy bespreking van die God van Israel merk Davies (1985:85) die onderskeid tussen die narratiewe en visioenêre dele van Daniël op. Waar dit in die vertellings gaan oor die heidense leiers se erkenning en prys van (maar nie bekering tot) die God van Israel, word hierdie leiers in die visioene slegs geteken as bestem vir God se oordeel, terwyl God se volk, wat deur hulle onderdruk word, gou verlos sal word. Davies (1985:86) se opsomming lui: "the stories are about harmony between Jew and Gentile, overseen by a providential God, the visions about a confrontation between Gentile and Jew, or, more accurately, Gentile king and God. Here God is the final destroyer of all Gentile kingdoms ..."' Die harmonie wat daar in hierdie opsig steeds tussen die vertellings en die visioene op te merk is, is dat dit in albei nie gaan oor godsdienstige botsings nie, maar oor politiek. Die vraag wat albei dele van die boek aanspreek is: "who rules history" (Davies 1985:86). Fewell (1991) het vir haar studie juis hierdie tema van 
politieke beheer oorgeneem. Die sentrale vraag van die boek Daniël is volgens Fewell (1991:12) "who rules?"

Dieselfde teologiese onderskeiding tussen die vertellings en die visioene wat sopas bespreek is, merk Davies (1985:88) ook op in sy bespreking van die God van die geskiedenis. In die vertellinge word daar gefokus op 'n verlossing op hierdie aarde ('n ingrype van God in die geskiedenis), terwyl die visoene fokus op 'n ingrype van God aan die einde van die geskiedenis. Die harmonie tussen hierdie uiteenlopende gesigspunte lê egter vir Davies (1985:88) daarin dat God sal verlos.

\section{2 'n Voorstel rondom die boodskappe in die boek Daniël vanuit 'n strukturele benadering}

Collins (2001:14) merk in ligter trant rondom die teologie van Daniël op dat die finale goddelike retribusie eers in die eskaton geverifieer sal word en daarom kan 'n teologie van Daniël wat hierop fokus nie bewys of ontken word nie. In 'n sekere sin open dit die deur dat enige voorstel in hierdie verband geldig kan wees. Goldingay (1989b) kan daarom 'n hele aantal teologiese temas in die boek voorstel. ${ }^{17}$ Anders as Goldingay (1989b) wat 'n hele aantal temas lys, poog die huidige voorstel om die struktuur van die finale teks te gebruik as "verifikasie" vir die voorstelle wat met betrekking tot boodskap(pe) in die boek Daniël gemaak word.

Hierbo is aangetoon dat die Aramese deel, sowel as die Hebreeuse deel van die boek konsentries gestruktureer is en dat die klem hiervolgens op die sentrale gedeeltes in daardie struktuur val (in die Aramees is dit hoofstukke 4 en 5 en in die Hebreeus is dit die gebed in hoofstuk 9). Die voorstel rondom die boodskap(pe) van die boek Daniël sal hierdie sentrale gedeeltes as fokus hê. Wat Daniël 1 betref is dit moeilik om te bepaal of daardie hoofstuk 'n afsonderlike (teologiese) funksie vervul en of dit slegs die leser se aandag wil fokus op die konsentriese struktuur wat in die daaropvolgende twee dele van die boek

17 In 'n meer resente en gefokusde werk rondom die teologie van Daniël toon Goldingay (2001:639-660) aan hoe die boek Daniël enersyds baie indirekte stellings aangaande God maak en andersyds hoe huidige lesers op meer as een vlak aansluiting kan vind by die menslike karakters in die boek. 
voorkom. Die konsentriese struktuur van hierdie inleidende hoofstuk sou volgens die laasgenoemde moontlikheid gesien kon word as "a set of institutional conventions forming codes [which] are possessed as linguistic competence by the members of the culture" soos Ray (1984:110) daarna verwys. Indien Daniël 1 egter 'n eie (teologiese) boodskap kommunikeer, sou dit verband hou met die handhawing van sommige religieuse gebruike te midde van 'n proses van herkulturalisasie (vgl. Goldingay 1989:24-25; Collins 1993:146).

Voordat op die sentrale dele van die boek Daniël soos hierbo uitgelig, gefokus word, verdien die inleidende deel by hoofstuk 2 (2:1-2:4a), wat nie in Aramees in die finale teks is nie, 'n kort opmerking. Hierdie deel vorm 'n eenheid met die res van hoofstuk 2 op die tematiese, sowel as die taalvlak. Tematies word die "probleem" van die koning (die droom wat hy gehad het) bekendgemaak en op taalvlak vorm die woorde "droom" en "bekendmaak" (in Hebreeus) deel van 'n refrein wat in die res van die hoofstuk (in Aramees) prominent is. Dit is moontlik dat die outeur hierdie inleidende verse in Hebreeus vertaal het (uit die Aramees) om sodoende die band met hoofstuk 1 duidelik uit te lig (vgl ook die gebruik van 'n soortgelyke inleidende sin as by hfst 1). Die direkte rede van die "Galdeërs" in die tweede deel van vers 4 het die geleentheid geskep om by wyse van 'n glos (Goldingay 1989:32) 'n organiese oorgang na die Aramees van die res van die hoofstuk te bewerk ( $\mathrm{vgl}$ Collins 1993:156).

In aansluiting by die aanvanklike opmerking dat die studieresultate nie volledig toegepas gaan word nie, word die voorstelle hier beperk tot die noemers van enersyds teologies- en andersyds sosiologies-georiënteerde boodskappe in die boek. Die teologiese fokus van die Aramese deel van die boek hou verband met die gedagte dat die Allerhoogste mag het oor die heerskappy van die mens ( $\mathrm{vgl}$ die verbatim herhaling van hierdie gedagte in 4:14, 22, 29 en in 5:21). Aardse vorste regeer dus by die grasie van die hemelse Vors. Hierdie sentrale gedagte dekonstrueer die skynbare magsvertoon van die heidense heersers in die deel van die konsentriese struktuur wat die sentrale deel omarm (hoofstukke 3 en 6). Daardie martelaarsverhale eindig met 'n dekreet wat die koning ten gunste van God uitvaardig. In die sentrale deel ontbreek hierdie dekreet en vind ons aan die begin van hoofstuk 4 'n doksologie wat eerder die teologiese fokus 
soos hierbo beskryf, onderstreep. Die buitenste komponente van die konsentriese patroon ondersteun die sentrale teologiese fokus wanneer die vernietiging van die heidense heerskappye in die vooruitsig gestel word. Die teologiese speerpunt is die gedagte dat God nou reeds implisiet regeer en aardse heersers slegs by sy grasie regeer, maar dat hierdie regering uiteindelik ook eksplisiet duidelik sal word met die vestiging van 'n finale en ewigdurende godsryk.

Die teologiese fokus van die Hebreeuse deel van die boek hou verband met ' $n$ blykbare teruggrype na ' $n$ ouer teologiese tradisie wat heelwat verskil van die teologie in die res die omliggende visionêre materiaal. ${ }^{18}$ Hierdie ouer teologiese tradisie is elders geïdentifiseer met die deuteronomistiese teologie ( $\mathrm{vgl}$ Van Deventer 2000). Hierdie tradisie, wat tydens die ballingskap ' $n$ antwoord moes bied op die vraag waarom só 'n lot die volk van die Here getref het (vgl die Deuteronomistiese Geskiedenis), herleef in die gebed van Daniël 9 te midde van ' $n$ soortgelyke en onverklaarbare lot wat die volk te beurt val - die vervolging deur Antiogus Epiphanes en sy ontwyding van die tempel in Jerusalem. Hierdie gebed herinner gelowiges, indiwidueel en kollektief, daaraan dat te midde van God se heerskappy oor alles, mense steeds aanspreeklik gehou sal word vir hulle optrede. Die determinisme van die apokaliptiese materiaal (vgl Osborne 1991:227) word deur hierdie gebed getemper. Alhoewel God oor die toekomstige lotgevalle van heidense heersers beskik, neem dit nie die verantwoordelikheid van sy volk weg om in die hede vas te hou aan sy wet en wil nie (vgl Dan 9:5, 10, 11, 13). Hierdie gebed koppel die lotgevalle van die volk direk aan hulle oortreding van God se gebooie en verordeninge.

Wanneer die aandag verskuif na ' $n$ meer sosiologies-georiënteerde bepaling van ' $n$ boodskap in die struktureel-geaksentueerde dele van die boek Daniël, word uitgegaan van die veronderstelling dat die gesag van tekste gemeenskapsgebaseerd is ( $\mathrm{vgl}$ Carr 1996) en verder verband hou met die behoud van ' $n$ bepaalde kulturele en religieuse identiteit te midde van ' $n$ krisis wat daardie identiteit bedreig (vgl Van der Kooij 1998:36; Noll 2001:18). In die tweede-eeuse Palestina sou die optrede van Antiogus Epiphanes die perfekte

18 Vgl Venter (1997) wat vanuit ' $n$ literatuurwetenskaplike hoek en meer spesifiek die bestudering van "intertekstualiteit" en "montage" 'n verklaring bied vir die behoud van hierdie twee gesigspunte langs mekaar. 
agtergrond bied vir die bedreiging van die Joodse identiteit. Dit is egter belangrik om in ag te neem dat hierdie identiteit nie noodwendig uniform was nie. Daar was meerdere faksies binne die Joodse bevolking, soveel so dat Carr (1996:47) verwys na "n "intense diversity" in die Judaïsme van die tweede eeu vC. 'n Religieuse teks sou enersyds meer as een siening moes huisves (Noll 2001:21), maar andersyds ook ' $n$ diverse gemeenskap saambind.

Wanneer die bogenoemde sosiologiese faktore in ag geneem word, lyk dit asof die fokuspunte van die boek Daniël gerig is op verskillende faksies binne die Joodse gemeenskap in antwoord op die vraag hoe daar opgetree moet word te midde van die vervolging deur Antiogus Epiphanes. Die verskillende antwoorde wat binne die Joodse gemeenskap op hierdie vraag gegee is, word in die fokuspunte van die boek Daniël weerspieël. Onder ' $n$ deel van die bevolking het die hoop bestaan dat die heidense regeerder tot inkeer sou kom (vgl Dan 4). Hierdie groep het dalk deel uitgemaak van ' $n$ politieke hoë-klas wat noue bande met die Seleukidiese magshebbers gehad het. ' $n$ Ander deel van die bevolking was oortuig dat die heidense heerser "verwyder" moes word (vgl Dan 5). Hierdie groep het die siening van 'n godsdienstige hoë-klas verteenwoordig, moontlik ' $n$ militante faksie van die Hasidim. ' $n$ Derde groepering het die fokus van die vraag weg van die heidense heerser verskuif en laat val op die Joodse gemeenskap. Hierdie groep het op kenmerkende deuteronomistiese wyse gevra na introspeksie om te bepaal waarom die volk in so ' $\mathrm{n}$ krisis gedompel is (vgl Dan 9:4-19). Die siening van die laasgenoemde groep hou moontlik ook verband met die godsdienstige hoë-klas, maar in hierdie geval eerder ' $n$ kwiëtistiese faksie in daardie groep (vgl Albertz 2001:201).

\section{SAMEVATTING}

Die benadering wat hier voorgestel is vir die blootlê van fokuspunte in die boek Daniël is, "suiwer" strukturalisties beskou, 'n hebried. Betekenis word daarin nie bloot beperk tot die "dieper" struktuur nie, maar daardie struktuur (soos bepaal aan die hand van 'n bepaalde literêre konvensie) word ingespan om 'n aanduiding te gee van die kern van die inhoud - dit waaroor die boek Daniël handel of waarop die boek betrekking mag hê (die boodskap[pe] van Daniël). In 
'n sekere opsig is die inhoud steeds primêr, maar dan nie bloot omdat dit inhoud is nie, maar 'n spesifieke (beklemtoonde) deel van die inhoud. Daardie spesifieke (beklemtoonde) deel is bepaal deur 'n strukturalistiese benadering tot die teks. Hierdie benadering poog verder om erns te maak met die historiese dimensie, sowel as literêre dimensie van die teks. Vanuit hierdie benadering kon enkele voorstelle gemaak word rondom moontlike boodskappe in die boek Daniël.

\section{Literatuurverwysings}

Aaron, C L 2001. Review of Buchanan, G W 1999, The book of Daniel. Lewistown: Mellen. CBQ 63(2), 308-309.

Albertz, R 2001. The social setting of the Aramaic and Hebrew book of Daniel, in Collins, J J \& Flint P (eds), The book of Daniel: Composition and reception, vol 1, 171-204. Leiden: Brill. (VT Supplement 83.)

Alter, R 1981. The art of biblical narrative. New York: Basic Books, Inc.

Alter, R 1987. Introduction to the Old Testament, in Alter, R \& Kermode F (eds), The literary guide to the Bible, 11-35. Cambridge: Belknap Press.

Baldwin, J 1978. Daniel: An introduction and commentary. Leicester: IVP.

Barton, J 1996. Reading the Old Testament: Method in biblical study. Revised and enlarged edition. London: Darton, Longman and Todd.

Bar-Efrat, S 1980. Some observations on the analysis of structure in Biblical narrative. VT 30(2), 154-173.

Bar-Efrat, S 1997. Narrative art in the Bible. Sheffield: Sheffield Academic Press.

Barthes, R 1977. Image music text, tr by S Heath. London: Fontana.

Brueggemann, W 1997. Biblical theology appropriately postmodern. BTB, 27(1), 4-9.

Burden, J J 1987. The book of Daniel, in Burden, J J \& Prinsloo, W S (eds), Dialogue with God, 197-222. Cape Town: Tafelberg. 
Carr, D M 1996. Canonization in the context of community: An outline of the formation of the Tanakh and the Christian Bible, in R D Weis, \& D M Carr, (eds), A gift of God in due season: Essays on Scripture and community in honor of J S Sanders, 22-64. Sheffield: Sheffield Academic Press.

Childs, B S 1979. Introduction to the Old Testament as Scripture. Philadelphia: Fortress.

Childs, B S 1989. Old Testament theology in a canonical context. Philadelphia: Fortress Press.

Clines, D J A \& Exum, J C 1993. The new literary criticism, in Exum, J C \& Clines, D J A (eds), The new literary criticism and the Hebrew Bible. Journal for the study of the Old Testament, 11-25. Sheffield: JSOT Press. (Supplement Series 143.)

Combrink, H J B 1988. Strukturalisme: Is 'n herwaardering nodig? NGTT 29(2), 129-138.

Collins, J J 1984. Daniel with an introduction to apocalyptic literature. Grand Rapids: Eerdmans. (FOTL.)

Collins, J J 1993. Daniel. Minneapolis: Fortress. (Hermeneia.)

Collins, $\mathrm{J} J$ 2001. Current issues in the study of Daniel, in Collins, $\mathrm{J} J$ \& Flint, $P$ W (eds), The book of Daniel: Composition and reception, vol 1, 1-15. Leiden: Brill.

Davies, P R 1988. Daniel. Sheffield: JSOT Press. (OTG.)

Deist, F E 1994. Onlangse konsepte in teksuitleg en hulle konsekwensies vir die (gereformeerde) teologie. In die Skriflig 28(2), 165-178.

Deist, F E 1996. Kanttekeninge by representasie in ou Hebreeuse literatuur. Tydskrif vir Letterkunde 34(4), 10-18.

De Saussure, F 1988a. The object of study, in Lodge, D (ed), Modern criticism and theory: $A$ reader, 3-9. London: Longman.

De Saussure, F 1988b. Nature of the linguistic sign, in Lodge, D (ed), Modern criticism and theory: A reader, 10-14. London: Longman.

Eagleton, T 1983. Literary theory: An introduction. Oxford: Basil Blackwell.

Eichrodt, W 1964. Theology of the Old Testament, vol 1 (Second impression), tr by J A Baker. London: SCM Press.

Eichrodt, W 1967. Theology of the Old Testament, vol 2, tr by J A Baker. London: SCM Press. 
Eissfeldt, O 1965. The Old Testament: An introduction. New York: Harper \& Row.

Fewell, D N 1991. Circle of sovereignty: Plotting politics in the book of Daniel. Nashville: Abingdon Press.

Fishbane, M 1982. I Samuel 3: Historical narrative and narrative poetics, in Gros Louis, K R R \& Ackerman, J S (eds), Literary interpretations of biblical narratives, vol 2, 191-203. Nashville: Abingdon.

Freeman, J A 1982. Samson's dry bones: A structural reading of Judges 13-16, in Gros Louis, K R R \& Ackerman, J S (eds), Literary interpretations of biblical narratives, vol 2, 145-160. Nashville: Abingdon.

Genette, G 1988. Structuralism and literary criticism, in Lodge, D (ed), Modern criticism and theory: A reader, 63-78. , London: Longman.

Goldingay, J 1989a. Daniel. Dallas: Word Books. (Word Biblical Themes.)

Goldingay, J 1989b. Daniel. Dallas: Word Publishing. (Word Biblical Themes.)

Goldingay, J 1993. Story, vision, interpretation. Literary approaches to Daniel, in Van der Woude, A S (ed), The book of Daniel in the light of new findings, 295-313. Leuven: Leuven University Press.

Goldingay, J 2001. Daniel in the context of Old Testament theology, in Collins, J J \& Flint, P W (eds), The book of Daniel: Composition and Reception, vol 2, 639-660. Leiden: Brill.

Harrison, R K 1969. Introduction to the Old Testament. Grand Rapids: Eerdmans.

House, P R (ed) 1992. Beyond form criticism: Essays in Old Testament literary criticism. Winona Lake, III.: Eisenbrauns.

Jacobson, R 1992. The structuralists and the Bible, in House, P R (ed), Beyond form criticism: Essays in Old Testament literary criticism, 101-117. Winona Lake, III.: Eisenbrauns.

Kaiser, W C \& Silva, M 1994. An introduction to biblical hermeneutics. Grand Rapids: Eerdsmans.

Lenglet, A 1972. La structure litteraire Daniel 2-7. Biblica 53, 69-90.

Longman, T 1993. The literature of the Old Testament, in Ryken, $L$ \& Longman, T (eds), A complete literary guide to the Bible, 95-107. Grand Rapids: Zondervan.

Milne, P J 1988. Vladimir Propp and the study of structure in Hebrew Biblical narrative. Sheffield: Sheffield Academic Press. 
Montgomery, J A 1927. A critical and exegetical commentary on the book of Daniel. Edinburgh: T\&T Clark. (ICC.)

Noll, K L 2001. The Kaleidoscopic nature of divine personality in the Hebrew Bible. Biblical Interpretation 9, 1-24.

Oosthuizen, M J 1994. The narratological approach as a means of understanding the Old Testament. Old Testament Essays 7(4), 84-91.

Osborne, G 1991. The hermeneutical spiral. A comprehensive introduction to Biblical interpretation. Downers Grove, III.: IVP.

Porteous, N W 1965. Daniel: A Commentary. Philadelphia: Westminster. (OTL.) Postmodern Bible cf Bible and culture collective.

Prinsloo, W S 1994. A comprehensive semiostructural exegetical approach. Old Testament Essays 7(4), 78-83. (Special Edition.)

Ray, W 1984. Literary meaning: From phenomenology to deconstruction. Oxford: Basil Blackwell.

Redditt, P L 1999. Daniel. Sheffield: Sheffield Academic Press.

Ryken L \& Longman, T 1993. Introduction, in Ryken, L \& Longman, T (eds), A complete literary guide to the Bible, 15-39. Grand Rapids: Zondervan.

Schultze, L F 1988. Strukturalisme en eksegese. NGTT 29(2), 139-153.

Shea, W H 1985a. Further literary structures in Daniel 2-7: An analysis of Daniel 4. Andrews University Seminary Studies 23, 193-202.

Shea, W H 1985b. Further literary structures in Daniel 2-7: An analysis of Daniel 5. AUSS 23, 277-295.

Snyman, S D 1996. 'n Struktureel-historiese benadering tot die eksegese van die Ou Testament. NGTT 37(4), 540-549.

Stevens, R K \& Stewart, L L 1987. A guide to literary criticism and research. New York: Holt, Rinehart and Winston.

The Bible and culture collective 1995. s v The postmodern Bible. New Haven: Yale.

Van der Kooij, A 1998. The canonization of ancient books kept in the temple of Jerusalem, in Van der Kooij, A \& Van der Toorn, K (eds), Canonization and Decanonization. Papers presented to the international conference of the Leiden Institute for the Study of Religions, 17-40. Leiden: Brill. (LISOR.) 
Van Deventer, H J M 2000. The End of the End: Or, what is the Deuteronomist (still) doing in Daniel, in De Moor J C \& Van Rooy H F (eds), Past, Present, Future: The Deuteronomistic history and the prophets 62-75. Leiden: Brill.

Venter, P M 1997. Intertekstualiteit, kontekstualiteit en Daniël 9. In die Skriflig 31(4), 327-346.

Von Rad, G 1965. Old Testament Theology, vol 2, tr by D M Stalker. Edinburgh: Oliver \& Boyd.

Wesselius, J-W 2001. The writing of Daniel, in Collins, J J \& Flint, P W (eds), The book of Daniel: Composition and Reception vol 2, 291-310. Leiden: Brill. 